instance of this is the lack of sufficient representation of science in the national delegations to Unesco. Prof. Auger put forward a proposal, which would be followed up in 1953, to form a scientific advisory committee on international scientific problems, and he thought that this might fill the gap.

Four countries which had joined the International Council of Scientific Unions since the last general assembly were then welcomed by the president, namely, Israel, Thailand, Spain and the German Federal Republic.

The International Mathematical Union was admitted as a new adhering organization. It was reported that the executive board had accepted provisionally an application from the Union of Physiology, and had not accepted applications from International Unions of Biochemistry, Nutritional Sciences, Scientific Psychology, Scientific Study of Population, and Philosophy of Sciences. A discussion followed in the case of the Union of Biochemistry, and it was agreed to recommend the continuance of discussions between representatives of the Union and of the Section of Bjochemistry of the Union of Chemistry in the hope that an agreed solution of the problem might be found; a member of the Council would be ready to assist in these discussions as an independent observer?

Certain changes of statutes were made: these included the creation of the post of treasurer, to lighten the task of the general secretary; the removal of the figure of the annual contribution due from countries and unions from the statutes (power was given to the general assembly to fix it for three years at a time); and a tightening of the conditions governing the admission of newly formed Unions.

A discussion took place on the plans for an International Geophysical Year in 1957-58, a successor to the International Polar Years of 1882 and 1932. On this occasion observations would be made not merely in polar regions but also in low latitudes. The proposal came originally from the Joint Commission on the Ionosphere, but jt was supported by the Unions of Astronomy, Geodesy and Geophysics, Radio-Sciences, Physics and Geography; the World Meteorological Organization is also co-operating. A small co-ordinating committee has been formed and it will meet very shortly, its convener being Col. E. Herbays, general secretary of the International Scientific Radio Union. Countries adhering to the Council have been asked to form national committees which would carry out the programme once it has been formulated, and the steering committee will, in due course, be enlarged. Other countries outside the Council are also being approached. Proposals for a redetermination of the network of world longitudes in the year 1957-58 were referred to the committee for inclusion in the general scheme. There was general agreement that a few special problems should be tackled : this was better than an attempt to gather a mass of observational data. As an example, the morphology of magnetic and ionospheric storms was mentioned by Prof. Berkner as a suitable problem. The year 1957-58 was selected as being one near sunspot maximum.

The assembly decided to urge its national adhering bodies to press for greater scientific representation on the national delegations to Unesco, and it also asked delegates to press for support of two international agreements drawn up by Unesco, on the importation and on facilitation of circulation of educational, scientific and cultural materials.
It was agreed to sever connexion with the Committee on Science and Social Relations, which has become a Joint Commission with the International Council of Philosophy and Humanistic Studies. The interests of the Committee had tended to move over from the purely scientific to the human and social side. After a discussion on the activities of the International Abstracting Board, it was agreed that to avoid confusion it should be known as the "I.C.S.U. Abstracting Board" or the "Bureau des Résumés analytiques de C.U.I.S.".

Sir Harold Spencer Jones, the Astronomer Royal, expressed the thanks of the assembly to the president for his distinguished services-the grace, humour and firmness with which he had presided over their meetings during the past three years, and also to the retiring general secretary, Prof. F. J. M. Stratton (Great Britain) for his devoted labours on behalf of the Council over a period of fifteen years.

The bureau of the Council for the next three years was elected as follows: President, Prof. B. Lindblad (Sweden); Retiring President, Prof. A. von Muralt (Switzerland); Vice-Presidents, Prof. H. Solberg (Norway) and Col. E. Herbays (Belgium) ; Treasurer, Prof. W. Albert Noyes (United States) ; Secretary General, Prof. A. V. Hill (Great Britain); Members, I'rof. J. P'érès (France) and N. Kameyama (Japan).

\section{SEVENTEENTH INTERNATIONAL GEOGRAPHICAL CONGRESS, WASHINGTON, D.C.}

CINCE 1871 an International Geographical Con$\checkmark$ gress has been held normally every three or four years, during the past half-century under the auspices of a continuing body, the International Geographical Union. The seventeenth Congress was held in Washington, D.C., during August 7-16 and attracted a record number of approximately fifteen hundred participants. Of these, more than twelve hundred were in personal attendance, and despite the difficulties of travel and dollar shortages some five hundred delegates from overseas countries were present, including approximately fifty from Great Britain.

To enable visiting delegates to see as much as possible of the work of their American colleagues, a number of other meetings were arranged at convenient times.

This is the centenary year of the American Geographical Society in New York, and the Society held open house during August 4-6 at its delightful premises in Broadway at 156th Street. At a special meeting of the Society, visiting scientific workers were honoured, Mr. J. M. Wordie, president of St. John's College, Cambridge, and president of the Royal Geographical Society and leader of the British delegation, receiving the Daly Medal.

During August 6-7 the Association of American Geographers and the National Council of Geography Teachers met simultaneously in Washington, D.C., and their meetings and joint banquet were attended by many delegates.

The attendance of so many from overseas in the United States was made possible by a generous provision of travelling fellowships and grants, particularly from the Wallace W. Atwood Senior Fund, 
administered with great generosity by his widow and family. Many American universities had previously arranged visiting professorships or lectureships, and those who gathered at Washington had, in many cases, already spent some time in different parts of the United States.

Nearly all the meetings were held in the Statler Hotel, where facilities had been arranged for a magnificent display of maps from many countries. After the official welcome, the opening general assembly and the official reception on August 8, the general arrangement was to have concurrent section meetings in the morning, and in the after noons to have concurrent meetings of those commissions which had been carrying on the work of the Union since the preceding Congress at Lisbon in 1949.

Certain broad topics of current world importance were considered by a series of symposia, and for all these important meetings simultaneous translations into IIrench, Spanish and English were available. The symposium on tropical Africa, under the chairmanship of Prof. Derwent Whittlesey (Harvard University), reviewed the progress of investigations in both the east and west. The necessity for continued study of those factors which naturally restrict possibilities of development was continually stressed.

Another symposium dealt with world food supply, and was under the chairmanship of Dr. C. E. Kellogg, chief of the United States Soil Survey. As so frequently happens, the speakers from the Old World, notably Prof. George Kuriyan (Madras), stressed the ever-present basic problem of shortage of land, whereas the speakers from the New World were concerned much more with technical problems of development or with economic aspects.

The retiring president, Dr. George Cressey (United States) gave his presidential address under the title "Land for $2 \cdot 4$ Billion Neighbors". The facts adduced leave no doubt that population is increasing far more rapidly than world food supply, and that the longrange solution, given the continued population increase, must be found in sources of food, for example from the sea, not yet regarded as practicable.

A large number of papers were presented at the section meetings which dealt respectively with geomorphology, the teaching of geography, climatology, urban and rural settlement, hydrography, resources, demography, cartography, biogeography, regional geography, historical geography, trade and transportation. In some marked contrast to previous meetings, there was strong support for the section on the teaching of geography, presided over by Prof. C. A. Alagoz (Turkey). Throughout the world there is the growing feeling that international understanding is threatened by the continued ignorance of the citizens of one country concerning the rest of the world, as well as, very often, ignorance of their home country. Instruction in this field is particularly weak throughout the schools and most of the universities of the United States; large gatherings of delegates pressed for a commission to examine the position and to make recommendations. Several of the sections showed an increasing awareness of the need for the application both of their methods of study and their research findings in the solution of some of the great problems of the day.

The same may be said of the afternoon meetings, when the reports of commissions, especially work carried out since the Lisbon Congress of 1949, were under consideration. The commissions reporting included those on industrial ports; medical geography (in the course of which Dr. Jacques May, head of the Medical Research Division of the American Geographical Society, displayed some of the magnificent maps he has in preparation); the international map of the world; regional planning ; arid zones; world land use; periglacial morphology ; and bibliography of ancient maps.

Normally a commission, limited to six full members, is appointed for one inter-congressional period but may, if its work is incomplete, be reappointed for a further period. No less than thirty-six proposals for commissions had to be considered by the executive, and many which might well have done useful work could not be appointed with any reasonable hope that even minimum financial support would be forthcoming. The final general assembly, having elected officers (see Nature, August 30, p. 347), set up eleven commissions to carry on the Union's work until the next Congress, which is planned to take place in Rio de Janeiro during August 1956.

The first four commissions are reappointments, and they are as follows (with the chairman shown in brackets) : periglacial morphology (Prof. M. A. Cailleux, France); medical geography (Dr. Jacques May, United States) ; inventory of world land use (Prof. S. Van Valkenburg, United States); and bibliography of ancient maps (Prof. Roberto Almagia, Italy). A sub-committee on the study of arid zones was constituted as a full commission under the chairmanship of Dr. Peveril Meigs (United States). The new commissions are : coastal sedimentation (Dr. Axel Schou, Denmark) ; erosion surfaces around the Atlantic (Prof. Francis Ruellan, France); evolution of slopes, including relevant aspect of soil erosion (Prof. Pierre Birot, France, and Prof. Paul Macar, Belgium); geography in schools (Prof. Neville Scarfe, Canada); karst phenomena (Prof. Herbert Lehmann, Germany); and library classification of geographical books and maps (Prof. A. Libault, France).

The commissions are dependent to a considerable extent on the receipt of communications from those who are interested all over the world, and the chairmen may be communicated with through the secretary-treasurer of the Union, Dr. G. H. T. Kimble, American Geographical Society, Broadway at 156th Street, New York 32, N.Y. L. Duduey Stramp

\section{INSTRUCTIONAL FILM RESEARCH}

$\mathrm{A}$ SHORT account of the Pennsylvania State College Instructional Film Research Program was given last year in Nature ${ }^{1}$, and now a report, written for this research programme, by Charles $\mathbf{F}$. Hoban, jun., and Edward B. van Ormer, has been published*, which reviews the research work done on the instructional film during the thirty-odd years prior to June 1950 at the Pennsylvania State College, and also other work independent of it. In the preparation of this report more than two hundred experimental and survey studies have been examined, and more than three hundred are noted in an appendix. These references are predominantly to

* Instructional Film Research 1918-1950. Technical Report No. $S D C$ 269-7-19. Pp. 200. (Special Devices Center, Port Washington, I.T., N.Y.) 